\title{
RITUAL AS INDICATIVE OF A CODE OF VALUES IN HEMINGWAY'S IN OUR TIME
}

\author{
Anna Stegh Camati \\ Universidade Federal do Paraná
}

\begin{abstract}
SUMMARY
This article discusses the concepts of ritual and code which Hemingway develops in his book In Our Time, which comprises a series of short-stories, intimately connected to one another, which tell us in chronological order about the childhood and adolescence of Nick Adams, known as the "Hemingway hero". In this book, which can be considered as an initiation ritual, we can observe the process of apprenticeship of Nick Adams, who tries to elaborate a code of ethics, that will permit him to live adequately in a world of violence, disorder and misery. In order to achieve his aims, he tries to acquire certain principles of honour, courage and endurance, which will allow him to conduct himself well despite the adversities he may encounter in life. In the last story of the book, entitled Big Two-Hearted River, we can observe a series of rituals symbolic of code: the ritualistic codified actions provide adequate metaphors for the 'inner code' of the protagonist.
\end{abstract}

\section{INTRODUCTION}

In his introduction to The Portable Hemingway, Malcolm Cowley suggests that Hemingway is a symbolic rather than a naturalistic writer, who "dealt in images that were symbols of an inner world." " He classifies his stories as "nightmares at noonday", which have a "waking dream-like

1 Cowley, M., ed, The Portable Hemingway. New York. Viking Press. 1944. p. vli. 
quality" ", since the modern anxieties and its manifestations are symbolically presented in them.

Concerning Hemingway's literary technique, a number of critics have compared his ability of evoking feeling through the sharp sensory detail to T. S. Eliot's theory of the 'objective correlative' In fact, his metaphors of violence and sometimes cruelty create a powerful tension, shocking the reader into emotional awareness. One of his favourite technical devices is the game metaphor, which can be regarded as an adequate 'objective correlative' for the existential contest as he sees it, since in games we also make up rules which impose limits to ourselves.

Earl Rovit states that the characters of Hemingway accept life as a kind of game, and that once they have made their commitment to the game, the contract is eternally binding." Life as a game prohibits absolute success, allowing only partial and disciplined success, always mixed with failure.

Although Hemingway sometimes seems imbued by Nietzschean pessimism, in his work as a whole his vision can be more closely related to modern existentialism: although there are hostile forces in the world that make it impossible for us to attain complete fulfilment, we are allowed to make our own choices, and having made a choice we must be prepared to cope with the consequences of our acts with dignity.

Hemingway insists that we have the power of will and that despite the adversities we may encounter, we can achieve a certain dignity if we believe in ourselves. He states clearly that man must have professional standards, a tested proce. dure or a 'code' to which he can adhere. For him, the bullfighter's ritual is the most elaborate symbol of code. He was the spokesman of the 'lost generation'", the spiritually exhausted, aimless survivors of World War I, to whom it had been revealed that life is no fair contest, affording neither

2 COWLEY. p. VIII.

3 RoVIT, E. Ernest Memingway. New York. Trayne, 1963, p. 33.

4 These !deas are clearly expressed in The Old Man and the Sea through the characterization of San!lago. 'Bee HEMINGWAY. E. The Old Man and the Sea. New York, Bcrtbner's Bons. 1952. 127 b.)

5 'Los: Generation' was cctred by Gertrude Stein and It is an appropriate term because th expreses will the mocd of expatrist:on. allenation and massive dislliuslonment with the traditional ralues in the 1920 's. 
satisfaction in victory, nor honour in defeat. The way of living of the Hemingway 'code hero' stands in direct opposition to everything the lost generation represents: he is never lost, his moral stance is stoical, and he is sustained by his personal honour, grimly enduring the hardships of life and achieving a certain degree of individual dignity and selfrespect. His code gives meaning to a world where there is iack of love and belief.

\section{GAME, RITUAL AND CODE}

Hemingway is a believer in the importance and significance of ritual. In a desacralized cosmos such as ours, man has to determine his own values, keeping up a code of honour and decency in the midst of general meaninglessness. He expressed this need of maintaining one's dignity through metaphors - the code which each individual has to work out for himself must be as consistent as that of ritualistic games - such as bullfighting, boxing, fishing and hunting which constitute activities acted out according to a strict, specific code. The metaphors of games provided him with a structure in which he could cast his ethics.

His fascination with bullfight is based precisely on the conviction that it is a ritualistic form of art. Not only does he accept bloodshed and death as integral partes of the ritual, but also believes in the mystique of pain and death. Suffering is for him an element of tragic catharsis, whereas the nearness of death provides man with lucid insight of himself and the world around him.

Hunting and fishing too have their rituals; while they are considered 'profane' activities in our time, the archaic world regarded them as 'sacred' ceremonies. According to Mircea Eliade, among primitive people "every act which has a definite meaning hunting, fishing, agriculture; games, conflict, sexuality - in some way participates in the sacred," because they constitute paradigmatic gestures that were acted out by mythical prototypes. The ritual then is the reenactment of some exemplary behaviour and it projects the indi-

6 ELLADE, M. The Myth of the Eternal Return. Princeton. Princeton University Press. 1974. p. 27-8. 
vidual into mythical time "when he is truly himself." " The function of ritual then is epiphany or regeneration and it is connected with the search for identity.

However, such activities as hunting and fishing, as well as struggles, conflicts and wars have undergone a long process of desacralization in the modern world, having lost their ritual cause and function. Because Hemingway advocates that the experience of fishing and hunting regenerates and develops character visibly, he has been considered a primitivist by some critics, although his ideas about ritual differ considerably from those of primitive societies. However, the basic idea is the same: through ritualistic experience man is stripped down to his essentials, becoming himself. Furthermore, there are other ideas implied in his concept of ritual, - for him ritual is the necessary condition for the formation of a code of values. His concept of individual ethics is connected with ritual. His most typical and admirable heroes, such as hunters, bullfighters and soldiers, are men whose life is guided by a rigid inner discipline, which constitutes a ritual-like code. The ritualistic codified actions such as bullfight and hunting provide adequate metaphors for the 'inner code' of such characters. They are always motivated by their own consciousness of what is right and wrong, by the rules of the game which they themselves have set up, and it is this way of behaving that constitutes Hemingway's ethics.

The character who lives up to such inward standards is referred to by Philip Young as 'code hero' - "this because he represents a code according to which the hero, if he could attain it, would be able to live properly in the world of violence, disorder and misery to which he has been introduced and which he inhabits. The code hero, then offers up certain principles of honour, courage, endurance which in a life of tension and pain make a man a man, as we say, and enable him to conduct himself well in the losing battle that is life." 8

7 ELIADE. The Mrth of the Eternal Return, p. 34

8 Hemingway's posture is similar to that of $W$. B. Yeats who declared in his autobiographical witings: "We begin to lire when we have concelved life as tragedy". (Bce YEATS. W. B. Autobiegraphies. Landon. Macmllian, 1973, p. 185). However, whlle reats teaches us the joyful acceptance of lost batiles, since the asserts that it is the strugzle itself that aatters. Hemingway taststs on the bitter aceeptance of the sdversities of life, teying to kecp up some sort of decencs and honour. Both of them. however. reject complete defeat. 
The conflict in Hemingway's stories and novels comes out of the contrast between the code hero and a weak and rather disorganized character, who is called the 'Nick Adams hero' by Philip Young. This kind of protagonist is a code learner, who gains some profit from the ritualistic experiences he witnesses and takes part in, and is able to some extent to apply his knowledge in a practical manner to his own life.

Earl Rovit refers to the Nick Adams hero as the 'tyro' and to the code hero as the 'tutor', affirming that it is basically an educational relationship that binds the two together, since the tyro tries to model his behaviour on the pattern he discerns from the tutor whose deliberate self-containment he admires. Although the tyro can never attain a state of serene unself-consciousness, he can learn the appearance of self-containment, training himself in the conventions which is the code, and by practicing these external restraints he can protect himself against the world."

While the action of the tutor is intuitive-instinctive, a a kind of consciousness of the body, that of the tyro is mental and reflective. The ritual which the tyro hero performs is not an entirely satisfactory ritual because he can't stop himself from thinking. The trained tyro though "unable to become a fully responsive mechanism of instincts", "can try to condition himself to force the right responses under stress." ${ }^{10}$ The quality of dignity, on which Hemingway insists so much, is manifested through the characterization of the tutor figures, and the great majority of them are non-American, such as Spanish bullfighters, Mexican gamblers, British white-hunters and so on.

According to Rovit, the sportsman's code is not the Hemingway code, but the former provides useful metaphors for the workings of the 'real code'. As life is imaged in terms of a game, the code which concerns Hemingway and his tyros is "the process of learning how to make one's passive vulnerability (to the dangers and unpredictabilities of life) into a strong, rather than a weak position, and how to exact

9 ROVIT, D. 55.

10 ROVIT, p. 60. 
ihe maximum amount of reward ("honour", "dignity") out of these encounters." "The Hemingway code is an ethic or philosophic perspective, which as I have already mentioned comes close to modern existentialism, since it tries to impart meaning and value to the seeming futility of life. "It also provides freedom for human actions within which morality can operate and human responsability can be judged in terms of active rather than passive responses." 12

Concluding, Rovit asserts that what Hemingway's tyro figures painfully learn and relearn consists of two lessons: "the ability to make realistic promises to oneself, and the ability to forgive oneself one's past," ${ }^{13}$ and that both of these capacities can be found analogically within the sportsman's code.

\section{THE RITUAL OF BECOMING IN IN OUR TIME}

In Our Time presents two distict sets of pieces, which alternate with one another: one is a series of short and brutal sketches of shootings, bullfight crises, hangings of criminals and war incidents, and the other is a collection of shortstories dealing with the growing up of Nick Adams, a boy from the American Middle-West, who in the process of apprenticeship comes to an awareness that the natural condition of life is pain and that man has to keep up a code of decency among the crude realities of violence and death.

Most of the vignettes are nightmare images that haunted Nick Adams, who is a tyro figure or code learner, shocking him into the recognition that life, like bullfighting, ${ }^{11}$ is a tragic game which one must learn to master with dignity. The vignettes also illustrate in contrapuntal fashion the chronological background of the stories. In the short section, called Chapter VI, we witness the turning-point or crisis in Nick's life. Nick, having been hit in the spine by machinegun fire, is sitting against the wall of a church. The repeti-

14 In a reporting arifle called Bull Fighting: a Tragedy. Hemingray says that bullighting is not a spcrt. "It is a tragedy. and it symbolizes the strucrle between man and the beasts". (Sce WuITE. $w$. ed. Ey-Line: Ernest Hemingray. New York. Bantam Books, 1970. p. 841. 
tion of the wall image becomes symbolic of a barrier to be transposed - there are a number of barriers that Nick had to transpose before he was able to make his "separate peace" 15 . Reading the vignette we understand that Nick's wound is more than physical - he has been wounded emotionally too. In order to be able to live with his scars he must learn to forget his past and impart meaning and value to the meaninglessness which he sees around him. This procedure is going to be shown in the form of ritualistic action in the last story of the book, which will be discussed in detail in the next section.

In the series of short-stories we can notice a considerable number of initiatory motifs and symbols. Some.of the scenarios are also initiatory and the ordeals that the hero undergoes conduct him from innocence to hard knowledge. Joseph Campbell's paradigm of the quest of the mythic hero can roughly be applied, since the stories can be grouped together in such a way as to suggest the formula represented in the rites of passage: separation (stories from one four), initiation (from four to thirteen), and return (the last story). ${ }^{16}$

These stages through which the protagonist passes on his way to becoming may be described as follows:

1. A state of pseudo-harmony and discord: Born in an upper middle-class milieu of Protestant respectability and conventionality, the tyro hero begins to lose faith and question old values. The first four stories deal with the progressive undoing of innocence of Nick Adams.

The first story Indian Camp can be considered a microcosm of the whole book, dealing with birth, pain and death; physical pain in birth and emotional pain in death. It is a story of initiation into violence and pain. There is an indication that emotional pain is harder to bear than physical suffering. The story becomes a metaphor of life, which in a sense consists of a series of operations without anaesthetics. Nick's first contact with the ritual of life is traumatic - at an early age he learns that life is tragic.

15 HEMINGWaY, E. In Our Time. New York, Scrlbner's Bons, 1958. p. 81.

16 Bee CAMPBELL, J. The Here with a Thousand Faces. Princeton. Princeton University Press, 1973. p. 30. 
In the next story, The Doctor and the Doctor's Wife the tutor father-figure who performed the ritual in Indian Camp, has been caught clearly intimidated by both the illiterate Indian bully and his wife. This perception pushes Nick a little farther along towards his independence. He learns that his father whom he admires so much is a fake.

The two next stories are companion pieces which com. plete Nick's initial phase. In The End of Something he faces how he really feels instead of what he thinks he ought to feel. The fishing ritual provides an adequate metaphor in the story for his working out of a new code of values.

The last story of the first section includes a drinking ritual, which also has metaphoric overtones. The drinking helps him to forget what he does not want to remember. Nick is rushing towards his own heart of darkness. He understands that he must separate himself entirely from his own social context, in order to find himself.

2. Wanderings and Ritual Experience: Nick Adams' wanderings begin in The Battler, which is a highly symbolic story in which the protagonist walks over a symbolic swamp, which denotes walking over insecure ground, being vulnerable to all sorts of disaster. Then he crosses a symbolic bridge, which represents "a transition from one state to another - of change or the desire for change." ${ }^{1}$ inally he sees a symbolic fire, a light spot against the threatening darkness, "the archetypal image of phenomena in themselves", 1s calling to our mind the significance of a ritual event in the midst of general meaninglessness.

The ritual experience or symbolic scene has an epiphanic effect on the young code learner, and in this sense it can be considered as a rite of passage. We have Nick's first encounter as a wanderer, when he meets Ad Francis, an ex-pugilist with distorted face and half-mad from his beatings. Francis is a code hero or tutor, who although he as been beaten by life, remained in a sense undefeated.

3. Return, which can be considered a relapse into pseudo-harmony: The last story of the book deals with the failure of the hero to become complete, which will be discussed in the next section.

17 CIRLOT, J. E. A Dictioniary of 5 ymbols. London, Routlegde and K. Paul, 1976. p. 33.

18 CIRLOT. D. 106. 


\section{RITUAL IN BIG TWO-HEARTED RIVER}

To illustrate Hemingway's concepts of ritual and code, I am going to concentrate on the last story in In Our Time, in which we can observe a series of rituals symbolic of code. The physical activities in the outdoor world, such as crossing burned-over land, making camp, preparing meal, looking ior baits and fishing trout, symbolize inner struggles. We understand that the story takes place in an inner world, and the fishing trip is a means for Nick Adams to escape from nightmares and unbearable realities. The hero is trying to get away from his past in order to be able to go on living. A feeling of release overpowers him when he leaves the burned country behind: "He felt he had left everything behind, the need for thinking, the need to write, other needs. It was all back of him." 10

The fishing ritual can be considered an exhausting ceremony of exorcism and a symbolic way of building up a code of values through ritualistic action. It is only by grasping the extent of Nick Adams psychic wounds that we can fully understand Big Two-Hearted River.

Concerning the initiatory scenario of the story we have two sinister places - the burned land and the swamp. The burned land symbolizes destruction and nightmare - a piece of land which Nick has tc cross before reaching a secure place which is the great plain where the river flows - the place where the exorcism will take place. Carlos Baker refers to Nick's crossing the burned-over land as a resistance ritual "', the interminable walkings prepare him for the ordeal. The swamp, on the other hand, symbolizes the hero's own heart of darkness, the experience accumulated in his unconscious mind which he is not yet able to digest.

After the resistance test follows the symbolic ritual of making camp. According to Mircea Eliade the building of a dwelling-place "represents a serious decision, for the very existence of man is involved; he must, in short, create his own world and assume the responsibility of maintaining and

19 HEMINGWAY, In Our Time, p. 179.

20 BAKER. C. Hemingway: o Escritor como Artista. Rlo de Janeiro. Civilizaclo Brasiletra, 1972. p. 143. 
renewing it." "1 The inauguration of a new dwelling is "in some measure equivalent to a new beginning, a new life." :2

This indication of creating one's own world and of having power to choose, which means that one has free will to build up one's own values, is strongly emphasized in the story, when Nick muses that: "He could have made camp hours before if he had wanted to. There were plenty of good places to camp on the river. But this was good." ${ }^{23}$ The idea of having constituted an 'imago mundi', "an existential sacred space" "24 or a code of values is also stressed: "Now things were done. There had been this to do. Now it was done. It had been a hard trip. He was very tired. That was done. He had made his camp. He was settled. Nothing could touch him. It was a good place to camp. He was there, in the good place. He was in his home where he had made it. Now he was hungry." 2s

After Nick has created the world he has chosen to inhabit comes the alimentation ritual, which implies the guarantee of continuity of life, "what we call 'vital values' was rather the expression of an ontology in biological terms" ${ }^{20}$ for the archaic man. Thus the alimentation ritual in which Nick re-enacts certain procedures to satisfy his biological needs has symbolic overtones, since the 'vital needs', the need for constituting an ontology, a mode of being in the world are implied. Now Nick is deciding what is right and what is wrong, taking as a basis his empirical experience: "I've got a right to eat this kind of stuff, if I'm willing to carry it," ${ }^{27}$ - this means he has a right to decide what is right and what is wrong if he is prepared to cope with the consequences.

Before the alimentation ritual there is also the ritual of building a fire. Fire is an objective correlative for the Hemingway code, 'the clean well-lighted place' in the midst of wilderness. Traditionally fire is an "agent of transmutation";"8

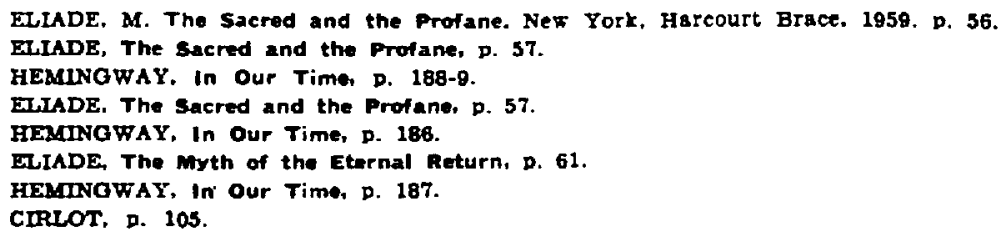


it implies both vital heat and destruction. Connected with the search of identity, the old self must be destroyed in order that the individual can be reborn.

In the second part of Big Two-Hearted River, we have the fishing ritual - on a metaphoric level we have the equation of life and game - which brings back the idea that man makes up the rules of the game, but once he has made them up he must follow them strictly. The fishing trip, then constitutes a metaphor for the 'inner code' of the hero. Nick Adams is a tyro hero, who tries to conduct himself maintaining certain principles of honour, dignity, decency, courage and endurance. However, he is not entirely successful in his fishing trip, although he succeeds in keeping up a code of decency and honour, he fails when his courage and endurance are tested.

While fishing he strictly observes the rules of the fisherman's code, in which he seems very well instructed. After having caught a small trout, he throws it back into the water, because he knows that the ritual of fishing demands that no life be wasted unnecessarily. Before doing so, he

stooped, dipping his right hand into the current. He held the trout, never still, with his moist right hand, while he unhooked the barb from his mouth, then dropped it back into the stream... He had to wet his hand before he touched the trout, so he would not disturb the delicate mucus that covered him. If a trout was touched with a dry hand, a white fungus attacked the unprotected spot. Years before when he had fished crowded streams, with fly fisherman ahead of him, Nick had again and again come on dead trout, furry with white fungus, drifted against a rock, or floating belly up in some pool. ${ }^{20}$

The ritual of fishing is connected with the ritual of 'wading' in the waters of the river. According to Eliade, "Immersion is equivalent to the dissolution of forms. This 
is why the symbolism of the waters implies both death and rebirth." 30

However, we see Nick's care of not immersing into "too deep" "31 waters, and his eagerness to avoid danger. He knew there were plenty of trout in the deep holes of the river, but "Nick did not care about fishing that hole. He was sure he would get hooked in the branches." "3 He also absolutely refuses to go fishing in the swamp:

He felt a reaction against deep wading with the water deepening up under his armpits, to hook big trout in places impossible to land them. In the swamp the banks were bare, the big cedars came together overhead, the sun did not come through, except in patches; in the fast deep water, in the half light, the fishing would be tragic. In the swamp fishing was a tragic adventure. Nick did not want it. He did not want to go down the stream any further today. ${ }^{33}$

Furthermore, all the time the young tyro hero feels rather 'awkward' and 'a little sick' in the ritual, we can see that he has learned the ritual and that he masters it quite well, but that it does not come naturally to him:

Nick felt awkward and professionally happy with all his equipment hanging from him... It was awkward getting his thumb inside the fly reel frame... Nick's hand was shaky. He reeled slowly. The thrill had been too much. He felt, vaguely, a little sick, as though it would be better to sit down. ${ }^{34}$

At the same time, he is also always conscious of the cruelty inflicted on the fish and even of the agonies endured by the live bait, the grasshoppers kicking the hook:

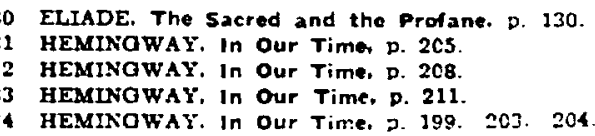


Nick knew the trout's teeth would cut through the snell of the hook. The hook would imbed itself in his jaw. He'd bet the trout was angry. Anything that size would be angry. That was a trout. Solid as a rock. He felt like a rock, too, before he started off... Nick lowered the rod and the hopper floated in. There was a heavy strike. Nick swung the rod against the pull. It felt as though he were hooked into the log itself, except for the live feeling. ${ }^{3 i}$

During the alimentation ritual in part one, there is a suggestion that Nick learned all the procedures of the ritual from a tutor figure called Hopkins, and that he is making an effort to act out everything according to the rules he has been-taught:

The coffee boiled as he watched... It was a triumph for Hopkins. He put sugar in an empty apricot pot and poured some of the coffee out to cool... It should be straight Hopkins all the way. Hop deserved that... Nick drank the coffee, the coffee according to Hopkins. ${ }^{36}$

Another detail that is important for the reader to observe is that Nick can't stop himself from thinking all the time. The example given before, which introduces the tutor figure Hopkins, is an indication that he does not act out the ritual intuitive or instinctivelly, but that he tries to condition him. self to force the right responses under stress. He is not only reflecting and imagining all the time, but he is also painfully aware that he is doing so. Throughout the story he is trying to tell himself that he feels happy, but it becomes more and more evident that he feels more 'awkward' than 'happy'. Here we have a suggestion of the painful rather than joyful acceptance of the life-ritual. The Hemingway hero accepts the restrictions of the game only under strain and pressure, and he is afraid of going too far into the swamps where he would probably encounter the danger to find himself. Therefore, the tyro hero is not reborn in the story; although there 
is clear evidence that he has learned a lot in the ritual process, the story ends with a suggestion that although he desires rebirth, he is still afraid of it; he is not yet ready to cope with the consequences of daring acts which require courage and endurance: "He was going back to camp. He looked back. The river just showed through the trees. There were plenty of days coming when he could fish in the swamp." 37

\section{CONCLUSION}

In Hemingway, the accomplished ritual is a guarantee of life, not happiness. In order to master life, the Nick Adams hero needs a code of values he can follow, a belief in certain zules by which to measure his behaviour. To supply him with this belief, he needs practical experience and the example of men who live and die by these rules.

In Big Two-Hearted River we see the failure of Nick Adams to become complete, because of his fear of going out as far as the swamp, since he is not yet prepared to face his own heart of darkness. Unlike Santiago in The Old Man and the Sea, Nick is reluctant to go out too far where his safety will be threatened. This is an indication that, although Nick has already learned that it is the discipline or code that gives man his full humanity, his education is not completed yet. He is not ready to summon up courage to face the threat that lies in wait for him; he refuses to penetrate the swamp where there is no firm ground, i. e., he does not want to bring to consciousness what is buried up in his unconscious mind. As he is not emotionally ready to face certain things which trouble him, he postpones the voyage into his own heart of darkness for some later occasion.

In his later work, Hemingway continued to tell the Nick Adams' story again and again: of the hero whose wounds are both literal and psychic, who fears death and is perplexed about the meaninglessness of the world, who needs to develop a private code to impose order to the confusion of the world, and who wants desperately to conquer his fears. 


\section{RESUMO}

O presente artigo investiga os conceitos de ritual e código que Hemingway desenvolve em sua obra In Our Time, que consiste de uma série de contos, intimamente relacionados, relatando em ordem cronológica a meninice e adolescència de Nick Adams, conhecido como o "herói de Hemingway". Nesta obra, que pode ser interpretada como sendo um ritual de iniciação, vemos o processo de aprendizagem de Nick Adams, que procura um código de ética que lhe permita viver em um mundo de violéncia, desordem e miséria. Para atingir seu objetivo procura adquirir certos princípios de honra, coragem e resistencia que the permitiräo enfrentar as adversidades da vida com digni. dade. No último conto do livro, intitulado Big Two-Hearted River, constatamos uma série de rituais que simbolizam o código: as açōes ritualisticas codificadas constituem metáforas adequadas para o "código interior" do protagonista.

\section{BIBLIOGRAPHICAL REFERENCES}

1 BAKER, C. Ernest Hemingway: a Life Story. New York. Scribner's Sons, 1969, $697 \mathrm{p}$.

2 BAKER, C. Hemingway: o Escritor como Artista. Rio de Janeiro, Civilização Brasileira, 1972. $426 \mathrm{p}$.

3 Campbel, J. The Hero with a Thousand Faces. Princeton, Prin. ceton University Press, 1973. $416 \mathrm{p}$.

4 CIRLOT, J. E. A Dictionary of Symbols. London, Routledge and K. Paul, 1976. $419 \mathrm{p}$.

5 COWLEY, M., ed. The Portable Hemingway. New York, Viking Press, 1944. $642 \mathrm{p}$.

6 ELIADE, M. The Myth of the Eternal Retum. Princeton, Princeton University Press, 1974. $195 \mathrm{p}$.

7 ELIADE, M. The Sacred and the Profane, New York, Harcourt, Brace, 1959. $256 \mathrm{p}$.

8 HEMINGWAY, E. In Our Time. New York, Scribner's Sons, 1958. $213 \mathrm{p}$.

9 HEMINGWAY, E. The Old Man and the Sea. New York, Scribner's Sons, 1952. $127 \mathrm{p}$.

10 ROVIT, E. Ernest Hemingway. New York, Twayne, 1963. 192 p.

11 WHITE, W., ed. By-Line: Ernest Hemingway. New York, Bantam Books, 1970. 428 p.

12 YEATS, W. B. Autoblographles. London, Macmillan, 1973. 592 p.

13 YOUNG, P. Ernest Hemingway. Minneapolis, University of Minnessota Press, 1965. $48 \mathrm{p}$. 